\title{
Utjecaj botaničkog sastava pašnjaka na imunosni status ovaca pasmine lička
} pramenka

\author{
D. Špoljarić, G. Kiš, K. Vlahović, I. Mujezinović, A. Hrković Porobija, L. Pajurin,
} T. Malone, S. Vince, V. Šegota, M. M. Kardum Paro, B. Špoljaric* i M. Popović

\section{Sažetak}

Procjena botaničkog sastava pašnjaka na različitim područjima s posebnim osvrtom na udjele terpena, koji osim učinka na terpenski profil arome mesa preživača mogu imati i potencijalni imunomodulacijski učinak, od bitnog je interesa suvremenog ovčarstva u R. Hrvatskoj. U istraživanjima u okviru ovog rada, pokazano je da ljekovite svojte bogate terpenima poput gospine trave (Hypericum perforatum L.), stolisnika (Achillea millefolium L.) i matičnjaka (Melissa officinalis L.) zbog statistički značajno veće učestalosti, gustoće i pokrovnosti na pašnjacima Velike Crkvine, $\mathrm{u}$ odnosu na pašnjake u Kvarte, potencijalno utječu na bolji imunosni status ovaca. Stoga su $\mathrm{u}$ ovom radu dobiveni rezultati znanstvena preporuka za daljnju procjenu biljnog sastava pašnjaka u Velikoj Crkvini tijekom istraživanja HRZZ projekta IP-2016-06-3685 u cilju postizanja dodatnih saznanja o učinku terpena na zdravlje i aroma sastav janjećeg mesa i to sve u svrhu proizvodnje inovativnih funkcionalnih proizvoda od janjećeg mesa.

Ključne riječi: pašnjak, terpeni, ovca

\section{Uvod}

Ljekovito bilje imalo je važnu ulogu u civilizaciji i povijesti naroda. Većinu biljaka izgrađuju bioaktivni sekundarni metaboliti koji posjeduju mnoga medi- cinski važna svojstva od interesa humane i veterinarske medicine. Naime, brojne ljekovite biljke ili njihovi dijelovi (korijen, stabljika, lišće, cvijeće, plod, sjemenka)

Dr. sc. Daniel ŠPOLJARIĆ, dr. med. vet., docent, dr. sc. Ksenija VLAHOVIĆ, dr. med. vet., redovita profesorica, Tom MALONE, student studija na engleskom jeziku, dr. sc. Silvijo VINCE, dr. med. vet., izvanredni profesor, dr. sc. Branimira ŠPOLJARIĆ ${ }^{*}$ (dopisni autor, e-mail: bzevrnja@vef.hr), dr. med. vet., docentica, dr. sc. Maja POPOVIĆ, dr. med. vet., redovita profesorica, Veterinarski fakultet Sveučilišta u Zagrebu, Zagreb, Hrvatska; dr. sc. Goran KIŠ, dipl. ing. agr., izvanredni profesor, Agronomski fakultet Sveučilišta u Zagrebu, Zagreb, Hrvatska; dr. sc. Indira MUJEZINOVIĆ, dr. med. vet., redovita profesorica, dr. sc. Amina HRKOVIĆ-POROBIJA, dr. med. vet., izvanredna profesorica, Veterinarski fakultet Univerziteta u Sarajevu, Sarajevo, Bosna i Hercegovina; Luka PAJURIN, dr. med. vet., asistent na projektu Hrvatske zaklade za znanost, Hrvatska; dr. sc. Vedran ŠEGOTA, dipl. ing. biol., stručni suradnik, Prirodoslovno-matematički fakultet Sveučilišta u Zagrebu, Zagreb, Hrvatska; dr. sc. Mirjana Mariana KARDUM PARO, spec. med. biokem., izvanredna profesorica, Klinička bolnica Merkur, Zagreb, Hrvatska 
ugodnog su mirisa, specifičnog okusa i često imaju specifično farmakološko djelovanje (Toplak, 2005.). U njihovoj citoplazmi nastaju eterična ulja kao produkt metabolizma, odnosno kao sekundarni metaboliti te se izlučuju u specifičnim uljnim stanicama ili šupljinama smještenim u biljnim organima. To su smjese biološki aktivnih kemijskih spojeva lako hlapivih svojstava koje imaju znatnu ulogu u zaštiti organizma, kod nedostatka vlage, hrane i sl. Dobro je poznato da su eterična ulja izvor brojnih biološki aktivnih spojeva koja se u narodnoj medicini koriste $\mathrm{u}$ različite svrhe zbog svoga antibakterijskog, antivirusnog, fungicidnog, antiparazitnog i insekticidnog djelovanja, a upotrebljavaju se i u kozmetičke svrhe. Sastav se eteričnog ulja može razlikovati između pojedine biljne vrste ili podvrste, kao i kod iste vrste s različitog lokaliteta zbog utjecaja ekoloških uvjeta. Eterična se ulja sastoje od lako hlapivih komponenti, koje svrstavamo u skupine: terpeni (monoterpeni, alifatski i ciklički, oksidirani i neoksidirani; seskviterpeni, alifatski i ciklički, oksidirani i neoksidirani; iterpeni, alifatski i ciklički, oksidirani i neoksidirani), fenilpropanski spojevi i ostali spojevi (neoksidirani ugljikovodici, alifatski i ciklički; oksidirani ugljikovodici, alkoholi, aldehidi, ketoni, eteri, esteri i karboksilne kiseline). Od velikog su interesa veterinarske medicine upravo terpeni. Naime, oni su hlapive tvari koje daju biljkama i cvijeću njihov karakterističan miris. Biološka i kemijska funkcija terpena $u$ biljkama još nije $u$ potpunosti prepoznata. Brojne biljke proizvode hlapive terpene $\mathrm{s}$ ciljem privlačenja određenih insekata u svrhu oprašivanja ili odbijanja pojedinih životinja. Terpeni imaju i važnu ulogu kao signalni spojevi i čimbenici rasta (fitohormoni). Brojni insekti metaboliziraju terpene iz biljaka i na taj način proizvode hormone rasta i feromone (Breitmaier, 2006.). Najčešći monotepreni koji se javljaju u eteričnim uljima su: $\alpha$-pinen, $\beta$-pinen, mircen, $\mathrm{p}$-ci- men, limonen, kamfor, timol, karvakrol, mentol te $\alpha$-terpinen za koje je u literaturi opisan i potencijalni imunomodulacijski učinak u monogastričnih i poligastričnih životinja (Kumar i sur., 2012., Zeng i sur., 2015., Balenović i sur., 2018., Ribeiro i sur., 2019., Valdivieso-Ugarte i sur., 2019., Yang i sur., 2019.). Većina biljaka iz porodice Labiateae kao osnovnu djelatnu tvar.

Nakon dugogodišnje uporabe $\mathrm{u}$ humanoj i veterinarskoj medicini spoznalo se da timol ima, prije svega dobro antibakterijsko djelovanje protiv velikog broja Gram-pozitivnih i Gramnegativnih bakterija. U veterinarskoj praksi dokazana je i učinkovitost timola u liječenju varooze pčelinjih zajednica (Mujezinović i sur., 2018.). Nadalje, prema istraživanjima Peterfalvi i sur. (2019.), esencijalna ulja pojedinih biljaka posjeduju imunomodulatorna svojstva na staničnoj i molekularnoj razini imunosnog sustava, odnosno na T stanice, citokine te na proizvodnju serumskih protutijela. U literaturi se spomenuti terpeni opisuju i kao mogući pouzdani biomarkeri zemljopisnog uzgoja. Naime, terpeni su isključivo metaboliti biljaka, pri čemu ih biljke dvosupnice sadrže znatno više u odnosu na biljke jednosupnice (Krvavica i sur., 2020.). Nadalje, u preživača zbog njihove fiziologije probave, terpeni se izravno iz hrane, bilo da se radi o paši ili sijenu, ugrađuju u njihova tkiva pri čemu terpenski profil njihovog mesa izravno ukazuje na područje njihovog uzgoja, odnosno botanički sastav pašnjaka na kojima su životinje uzgajane.

Pajurin i sur. (2020.) opisali su da bogatstvo i raznolikost flore R. Hrvatske čine 4462 vrste i 1131 podvrsta, uključujući 349 endema i 96 stenoendema na ukupnoj državnoj površini od $~ 56000 \mathrm{~km}^{2}$, pri čemu je opće poznato da je njihova iskoristivost od ukupnih biljnih vrsta nekog područja $>20 \%$ i to za prehranu i stočnu hranu, odnosno u medicinske svrhe, u tekstilnoj i kemijskoj industriji, u hortikulturi i 
drugdje. Prema dostupnim podatcima, u R. Hrvatskoj distribucija flore nije sustavno istražena (Nikolić, 2006., Nikolić, 2013.). Tako, temeljem dostupnih literaturnih podataka o hlapivim sastojcima dalmatinske, ličke, paške i kupreške janjetine, pretpostavka je da zemljopisno područje uzgoja, odnosno botanički sastav pašnjaka na kojima se janjad uzgaja ima značajan učinak na aroma sastav janjećeg mesa (Krvavica i sur., 2015.a,b,c, Krvavica i sur., 2016., Krvavica i sur., 2020.). Većina se autora slaže da postoji mogućnost identifikacije i praćenja specifičnih biljnih biomarkera u proizvodima i tkivima životinja koji se pouzdano mogu povezati s načinom hranidbe i hranom, pri čemu meso janjadi uzgojene na paši sadrži više fenola, terpena, indola i sumpornih spojeva (Cvrtila i sur., 2018.). Pri tomu značajni doprinos na formiranje arome tipične za pojedine vrste janjetine imaju terpeni koji se izravno iz biljaka ugrađuju u tkiva preživača ili nastaju kao rezultat razgradnje klorofila pod utjecajem mikroflore buraga (Vasta i Priolo, 2006.). U literaturi se opisani učinak opisuje kao "terroir effect" ili "efekt teritorija" (Krvavica i sur., 2015.a). Krvavica i sur. (2015.b) su u svojim istraživanjima opisali da se aroma ličke janjetine podrijetlom od janjadi uzgojene na području Like sastoji od 34 hlapiva spoja od kojih su 2 terpena (kariofilen i $\alpha$-kopaen). Od predhodno navedenih 34 hlapiva spoja $u$ sastavu arome dalmatinske janjetine nije ustvrđeno njih 9, dok aroma ličke janjetine ne sadrži čak 23 hlapiva spoja koja su ustvrđena $\mathrm{u}$ aroma sastavu dalmatinske janjetine (Krvavica i sur., 2015.c). U okviru HRZZ projektnih aktivnosti (IP2016-06-3685) paša predstavlja temeljni obrok stada ovaca/janjadi pasmine lička pramenka, budući da životinje borave na pašnjacima gotovo tijekom cijele godine. Naša su opažanja tijekom terenskog rada na ispaši, u suglasju sa zapažanjima
Mioč i sur. (2007.). Naime, poznato je da su ovce/janjad vrlo izbirljive, jer najprije jedu list i cvijet, a tek nakon toga stabljiku (Vanden Broeck i sur., 2015.). Njihov obrok sadrži veliki broj biljnih vrsta, trava i leguminoza, u okviru kojeg konzumiraju bioaktivne molekule, odnosno smjese terpenoidnih spojeva. Stoga je od velikog interesa pratiti kvalitativne i kvantitativne promjene $\mathrm{u}$ odabranom staništu, odnosno mjerenja ili procjenjivanja promjena u broju i sastavu značajnih ili svih biljnih vrsta (npr. učestalost, gustoća, pokrovnost) staništa, s osobitim osvrtom na ljekovite svojte čiji terpeni potencijalno istovremeno pozitivno djeluju na zdravlje životinje i na aroma sastav profila njihovog mesa i proizvoda namijenjenih za prehranu ljudi. Stoga, zbog sve većeg interesa znanstvene javnosti za procjenom mogućeg imunomodulatornog učinka terpena iz biljaka, cilj istraživanja ovog rada je procjena imunosnog statusa ovaca ovisno o botaničkom sastavu pašnjaka, odnosno o učestalosti, gustoći i pokrovnosti ljekovitih svojti poput majčine dušice, gospine trave, mente i stolisnika.

\section{Materijali i metode}

\section{Procjenjivana svojta}

Krajem lipnja 2017. godine na 20 ha pašnjaka u Kvarte, Lika te krajem lipnja 2018. godine na 20 ha pašnjaka u Velikoj Crkvini, Kordun zabilježene su u punom cvatu sljedeće svojte: gospina trava (Hypericum perforatum L.), stolisnik (Achillea millefolium L.) i matičnjak (Melissa officinalis L.). S obzirom da su navedene svojte bile, subjektivnom procjenom, različite učestalosti, gustoće i pokrovnosti pristupilo se njihovoj procjeni prema modelu Pajurin i sur. (2020.). Sve svojte procjenjivane su na plohama kao busenovi krajem lipnja 2017. i 2018. te su svi rezultati bili pohranjeni do trenutka statističke obrade tijekom 2020. godine. 

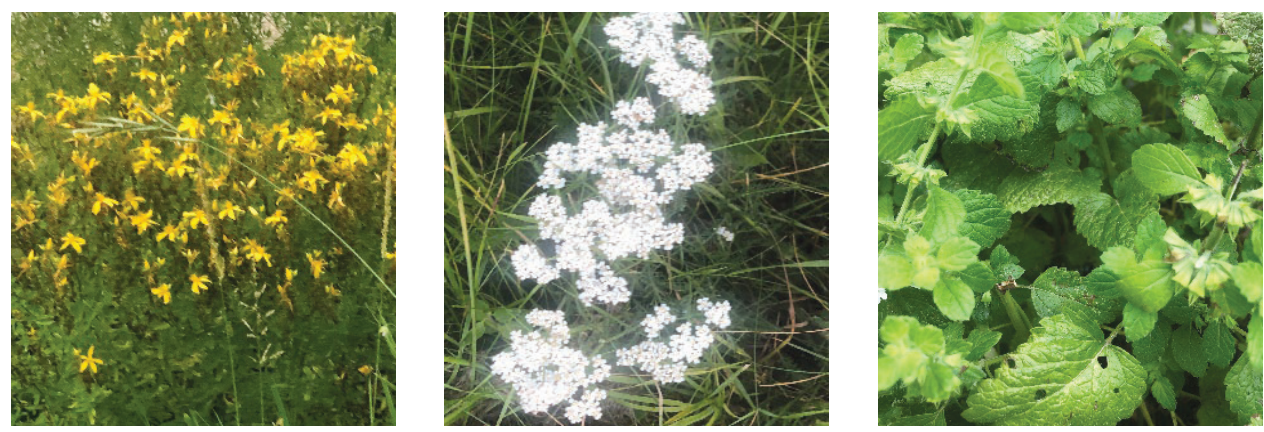

Slika 1. Buseni gospine trave (Hypericum perforatum L.), stolisnika (Achillea millefolium L.) i matičnjaka (Melissa officinalis L.) na procjenjivanim pašnjacima
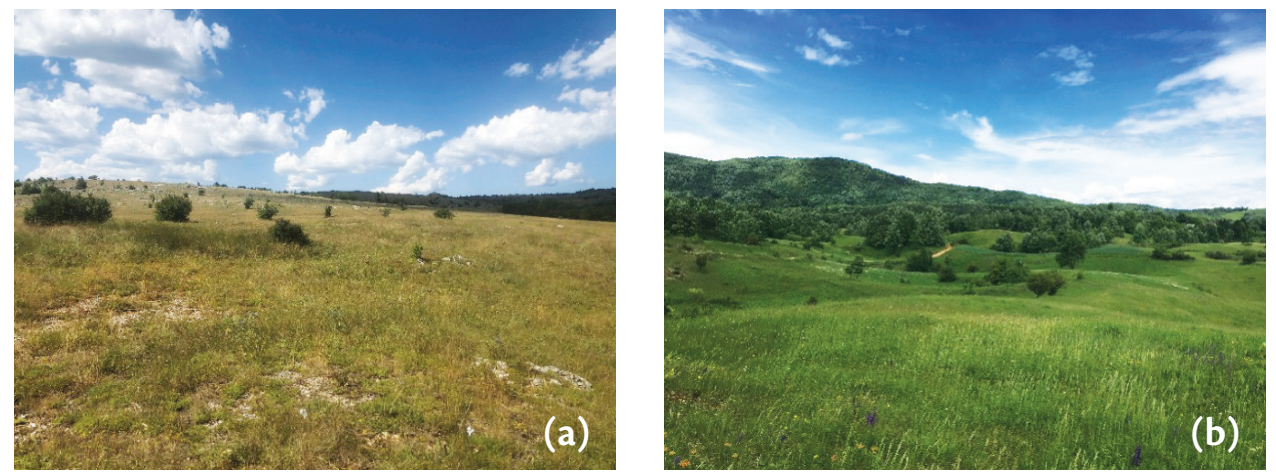

Slika 2. Procjenjivani pašnjaci pašnjaka u Kvarte, Lika (a) i u Velikoj Crkvini, Kordun (b)

Za dokumentiranje nalaza svojti na pašnjacima u Kvarte i u Velikoj Crkvini digitalnim su fotoaparatom napravljene snimke prikupljenog herbarijskog primjerka biljke te panoramske snimke staništa i ploha (Slika 1.).

\section{Veličina, položaj, trajnost i broj ploha procjenjivanog staništa}

Krajem lipnja 2017. godine na 20 ha pašnjaka u Kvarte, Lika te krajem lipnja 2018. godine na 20 ha pašnjaka u Velikoj Crkvini, Kordun, namjernim odabirom položaja postavljeno je 10 jednokratnih ploha preporučljive minimalne veličine sukladno biljnom pokrovu livade od $25 \mathrm{~m}^{2}$. Svaka ploha površine $25 \mathrm{~m}^{2}(100 \%$ promatrane površine), podijeljena je na 25 kvadrata, svaki s površinom od $1 \mathrm{~m}^{2}$ (Pajurin i sur., 2020.) (Slika 2.).

\section{Procijena učestalosti, gustoće i pokrovnosti svojte}

$\mathrm{Na}$ svih 10 odabranih ploha oba pašnjaka procjena učestalosti, gustoće i pokrovnosti za svaku procjenjivanu svojtu napravljena je prema modelu Pajurin i sur. (2020.).

\section{Životinje}

Krajem lipnja 2017. godine na 20 ha pašnjaka u Kvarte, Lika boravilo je stado od 200 ovaca pasmine lička pramenka. Stado je u cjelosti tijekom ožujka 2018. godine preseljeno na 20 ha pašnjaka u Velikoj Crkvini, Kordun. Za potrebe HRZZ projekta "Inovativni funkcionalni proizvodi od janjećeg mesa" (IP-2016-063685) odabrano je krajem lipnja 2017. godine 45 ovaca $u$ dobi od 2-4 godine kojima je izvađena krv za višebojnu 

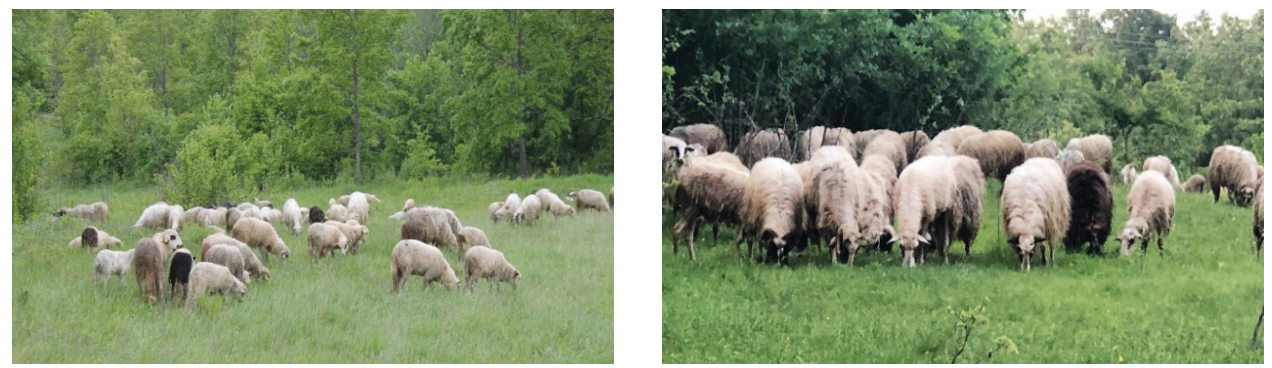

Slika 3. Stado ovaca pasmine lička pramenka na procjenjivanim pašnjacima

protočnu citometrijsku analizu. Krajem lipnja 2018. godine istim životinjama, u dobi od 3-5 godina također je izvađena krv za višebojnu protočnu citometrijsku analizu (Slika 3.). Ovo istraživanje dio je HRZZ projekta "Inovativni funkcionalni proizvodi od janjećeg mesa" (IP-2016-063685) za koje je dobivena Odluka Etičkog povjerenstva $u$ veterinarstvu (klasa 640-01/16-17/54; Ur. broj 25161-01/13916-2) od strane Veterinarskog fakulteta Sveučilišta u Zagrebu i Rješenje od Ministarstva poljoprivrede R. Hrvatske, Uprave za veterinarstvo i sigurnost hrane Hrvatske (klasa: UP/I-322-01/17-01/31; Ur. br.: 525-10/052917-2).

\section{Višebojnu protočnu citometrijska analizu}

Višebojna protočna citometrijska analiza T- i B-limfocita iz uzoraka periferne krvi ovaca napravljena je na protočnom citometru (Slika 4.) prema protokolu kojeg su opisali Valpotić i sur. (2014.) koristeći fluorokromom direktno obilježena specifična mišja monoklonska protutijela za sljedeće kombinacije antigena leukocita ovaca:

- citolitički T-limfocite (panel:

$\mathrm{CD}_{4}{ }^{+} \mathrm{CD}^{+} \mathrm{CD}^{+} \mathrm{CD}^{-} \mathrm{CD}^{-} 1^{-}$): protuCD45:FITC/protu-CD3:Pacific Blue ${ }^{\circledR}$ protu-CD8:PE (BIO-RAD);

- pomoćnički T-limfocite (panel: $\mathrm{CD} 45^{+} \mathrm{CD}^{+}{ }^{+} \mathrm{CD} 8{ }^{-} \mathrm{CD} 4^{+} \mathrm{CD}^{-} 1^{-}$): protuCD45:FITC/protu-CD3:Pacific Blue ${ }^{\circledR}$ protu-CD4:Alexa FLUOR® $\quad$ (BIORAD);

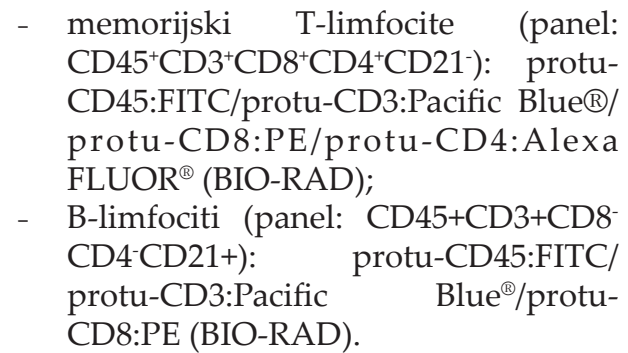

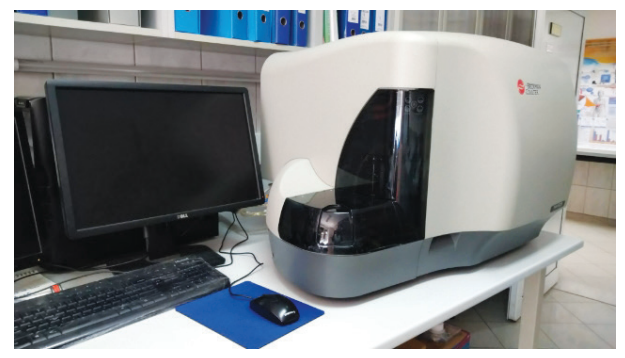

Slika 4. Višebojni protočni citometrar (Beckman Coulter Navious) smješten u Kliničkom zavodu za medicinsku biokemiju i laboratorijsku medicinu, Klinička bolnica Merkur, Zagreb, Hrvatska

\section{Statistička analiza podataka}

Statistička analiza podataka odrađena je pomoću programskog paketa SAS 9.4 (Statistical Analysis Software 2002-2012 by the SAS Institute Inc., Cary, USA).

Statistička analiza ukupne populacije procjenjivanih ljekovitih svojti na pašnjacima uključivala je opisnu obradu osnovnih statističkih parametara (PROC FREQ, PROC MEANS). Za dostatan broj mjerenja populacije ljekovitih svojti $(n=10$, koja su provedena tijekom istraživanja) odstupanja od srednje vrijednosti se 
s povećanjem mjerenja se znatno ne mijenjaju, što je potvrđeno procjenom standardne pogreške srednje vrijednosti (engl. standard error, SE). Procjena ljekovitih svojti na ukupnoj površini pašnjaka provedena je izračunom gustoće prema procjenjivanoj plohi i gustoće prema Braun-Blanquetu skali $s$ pet stupnjeva. Kako bi se ustanovila razlika između ljekovitih svojti na dva pašnjaka rađena je dvosmjerna analiza varijance (PROC ANOVA).

Statistička analiza T i B limfocita periferne krvi uključivala je test normalnosti korištenjem procedure UNIVARIATE. U slučajevima velikog rasipanja podataka oko srednje vrijednosti, pomoću procedure ROBUSTREG uklonjene su ekstremne vrijednosti. Određivanje statističke značajnosti između dva nezavisna uzorka rađena je pomoću t-testa (PROC TTEST). Analiza je smatrana statistički značajnom ako je $P<0,05$.

\section{Rezultati i rasprava}

Još se tijekom 2017. godine provedba „Programa uzgoja ovaca u Republici Hrvatskoj", kao temeljnog dokumenta $u$ organizaciji i provedbi uzgojno selekcijskog rada $u$ ovčarstvu, odvijala $\mathrm{u}$ okviru aktivnosti poput kontrole reproduktivnih osobina u stadima ovaca uzgajivača upisanih u Upisnik uzgajivača uzgojno valjanih grla, kontrole mliječnosti u stadima mliječnih i kombiniranih pasmina ovaca, provedbom performance testa odabrane muške janjadi $u$ field uvjetima, izračunom procjene uzgojnih vrijednosti za sve mliječne pasmine ovaca prema BLUP (engl. Best Linear Unbiased Prediction) metodi izračuna, suradnjom s Hrvatskim savezom uzgajivača ovaca i koza u provedbi uzgojno selekcijskog rada i edukacijama uzgajivača kroz organizaciju predavanja $\mathrm{s}$ različitim temama vezanim uz poboljšanje ovčarske proizvodnje. Svi postupci u provođenju kontrole proizvodnih osobina su $\mathrm{u}$ skladu s procedurama propisanim ICAR-om (engl. International Committee for Animal Recording), međunarodnom organizacijom za provođenje kontrola u stočarstvu (Sinković i Čačić, 2018.). Od ukupnog broja ovaca u Republici Hrvatskoj najveći broj uzgojno valjanih grla uzgajao se u Zadarskoj (9.051 grlo ili 22,19 \%) i Ličko-senjskoj županiji (8.559 grla ili 20,98\%), dok je najveći broj uzgajivača raspoređen u Sibenskokninskoj (78 stada ili 20,10 \%) i Zadarskoj županiji (64 stada ili 16,49 \%). Na našim otocima i priobalju ukupno se uzgaja više od 80 \% uzgojno valjanih ovaca što dokazuje činjenicu tradicijskog uzgoja na ovim područjima gdje je ovčarstvo glavna stočarska grana proizvodnje. Najmanji broj uzgojno valjanih ovaca i uzgajivača je u Virovitičko-podravskoj i Zagrebačkoj županiji. Devedeset posto uzgajanih ovaca čine hrvatske autohtone pasmine: dalmatinska pramenka, dubrovačka ruda, cigaja, creska ovca, istarska ovca, krčka ovca, paška ovca, rapska ovca i lička pramenka (Vince i sur., 2017.). Pretpostavlja se da se danas uzgaja oko 12000 umatičenih ovaca i ovnova ličke pramenke, stoga se ne može govoriti o ugroženosti ove pasmine. U budućnosti je nužno odrediti točan broj grla te definirati populaciju koju treba zaštiti od miješanja s drugim genotipovima (Sinković i Čačić, 2018.). Po broju umatičenih grla je treća po veličini populacija, poslije dalmatinske pramenke i paške ovce (Sinković i Čačić, 2018.), a uzgaja se u stadima prosječne veličine od 168 grla (Mulc i sur., 2012.). Pramenka je dobila ime po otvorenom runu s jasno uočljivim pojedinačnim pramenovima. To je pasmina koja je inače rasprostranjena $u$ širem području jugoistočne Europe. Glava, donji dijelovi tijela i noge te pasmine obrasli su dlakom, a ostali dio tijela vunom. Ovnovi imaju snažne rogove, a ovce su najčešće bez rogova. Boja vune je pretežito bijela, ali učestalo se javlja i siva, smeđa ili crna boja vune. U većine 
bijelih grla na glavi i nogama javljaju se točkasta i veća područja tamne dlake. Jedno od najvažnijih osobina pramenke jest njezina velika otpornost i izdržljivost za kretanje na velike udaljenosti te dobro iskorištavanje travnjaka lošije kakvoće. Tjelesna masa je jedno od obilježja koje pokazuje najveći opseg varijacija. Tako je, ovisno o uvjetima hranidbe, tjelesna masa ovaca od 25 do $70 \mathrm{~kg}$, a ovnova od 30 do $90 \mathrm{~kg}$. Runo je otvorenog tipa, sa šiljastim pramenovima, a finoća vlakna je prosječno 30 do 50 mikrona. Godišnji nastrig vune je nizak, od 1,0 do 3,0 kg. Duljina pramenova je od 12 do preko 20 $\mathrm{cm}$, a randman vune je relativno visok (50 do $70 \%$ ). Pramenke su izrazito kasnozrele ovce koje se prvi put pripuštaju u dobi od godine i pol. Plodnost ovaca je prosječno $90 \%$. Porodna masa janjadi je od 2 do 4,5 kg. Proizvodnja mesa po ovci je niska. Janjad se kolje s malom tjelesnom masom, prosječno oko $20 \mathrm{~kg}$ žive vage. Prosječna proizvodnja mlijeka u pramenke je varijabilna i kreće se od 30 do $60 \mathrm{~L}$ (bez mlijeka koje posiše janje) u laktaciji koja traje oko šest mjeseci. Klaonička iskoristivost zaklane janjadi je relativno niska i kreće se oko $45 \%$. Međutim, kakvoća mesa je izvrsna i stoga se smatra kulinarskim specijalitetom. Naime, kakvoću janjećeg mesa konzumenti najčešće procjenjuju temeljem okusa i arome toplinski obrađenog mesa, a koje se s obzirom na zemljopisno područje uzgoja razlikuje (Krvavica i sur., 2020.). Tako, Priolo i sur. (2004.) napominju da je aroma profil (sastav hlapivih spojeva) janjećeg mesa ovisan o pasmini te o sustavu uzgoja, odnosno o sastavu dnevnog obroka što uključuje i botanički sastav pašnjaka. Krvavica i sur. (2020.) napominju da je upravo geografsko područje ispaše važan čimbenik koji utječe na formiranje specifične arome životinjskih proizvoda, odnosno da terpeni iz biljaka pri tome imaju vrlo znatnu ulogu. Stoga, iz svega prethodno navedenog od interesa je suvremenog ovčarstva procjena botaničkog sastava pašnjaka na različitim područjima $i$ to s posebnim osvrtom na udjele terpena. Pajurin i sur. (2019.a,b) opisuju da su travnjacima $\mathrm{u}$ ispaši $\mathrm{s}$ područja Velike Crkvine (zemljopisne koordinate: $45^{\circ} 18^{\prime} 46.8^{\prime \prime} \mathrm{N}, 15^{\circ} 31^{\prime} 30^{\prime \prime}$ ) pripadaju suhim kontinentalnim travnjacima na vapnencima iz razreda Festuco-Brometea i reda Brometalia erecti, za razliku od krških pašnjaka na području Kvarte (zemljopisne koordinate: $44^{\circ} 40^{\prime} 42.1^{\prime \prime} \mathrm{N}$ $\left.15^{\circ} 23^{\prime} 12.6^{\prime \prime}\right)$. U ovim istraživanjima, na promatranim pašnjacima krajem lipnja 2017. (Kvarte) i krajem lipnja 2018. godine (Velika Crkvina) temeljem provedenih kombiniranih procjena ljekovitih svojti $\mathrm{u}$ vegetacijskim snimkama zabilježene su gospina trava (Hypericum perforatum L.), stolisnik (Achillea millefolium L.) i matičnjak (Melissa officinalis L.) Iz Tabele 1. je vidljivo da procjenjivane ljekovite svojte na pašnjaku u Velikoj Crkvini imaju statistički značajno veću učestalost, gustoću i pokrovnost u odnosu na iste na pašnjaku u Kvarte $(P<0,05)$. U ovom radu nije provedena usporedna kombinirana procjena između dva pašnjaka s obzirom na učestalost, gustoću i pokrovnost majčine dušice (Thymus pulegioides L.) jer navedena svojta nije zabilježena $u$ vegetacijskim snimkama pašnjaka u Kvarte na kraju lipnja 2017. godine. Međutim, Pajurin i sur. (2020.) su u Velikoj Crkvini na 20 ha površine procijenjenog pašnjaka zabilježili da majčina dušica (Thymus pulegioides L.) ima zamjetnu procjenu učestalosti od 19,2\% $\pm 4,54 \%(95 \%$-tne granice pouzdanosti $10,77-27,64 \%$ ) i mjerenu gustoću po kvadratnom metru od 0,26 $\pm 0,09$ (95\%-tne granice pouzdanosti $0,09-0,44$ ), odnosno

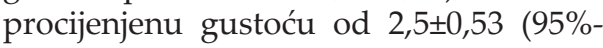
the granice pouzdanosti 1,52-3,48) stupnja prema Braun-Blanquetu skali s pet stupnjeva od ukupno determiniranih ljekovitih i aromatičnih vrsta lipnja 2019. godine. Nadalje, njezina je pokrovnost procijenjena dronom iznosila $15,8 \pm 2,20$ 
Tabela 1. Srednje vrijednosti i standardna pogreška srednje vrijednosti parametara ljekovitih svojti na dva različita procjenjivana pašnjaka.

\begin{tabular}{l|l|c|c|c|}
\multirow{2}{*}{ Parametar } & \multirow{2}{*}{ Pašnjak } & \multicolumn{3}{|c|}{ ljekovita svojta na 20 ha pašnjaka } \\
\cline { 3 - 5 } & Velika Crkvina & $10,8 \pm 0,8$ & $10,0 \pm 0,8$ & $7,6 \pm 0,7^{*}$ \\
\hline \multirow{2}{*}{ Učestalost (\%) } & Kvarta & $9,6 \pm 0,8$ & $8,4 \pm 0,7$ & $5,2 \pm 0,6^{*}$ \\
\hline \multirow{2}{*}{ Gustoća (X/25) } & Velika Crkvina & $0,28 \pm 0,01$ & $0,24 \pm 0,01$ & $0,21 \pm 0,01^{*}$ \\
\hline \multirow{2}{*}{$\begin{array}{l}\text { Gustoća prema } \\
\text { Braun-Blanquet skali }\end{array}$} & Kvarta & $0,27 \pm 0,01$ & $0,24 \pm 0,01$ & $0,15 \pm 0,01^{*}$ \\
\hline & Kvarta & $2,6 \pm 0,1^{*}$ & $2,3 \pm 0,1^{*}$ & $2,0 \pm 0,1^{*}$ \\
\hline
\end{tabular}

*označava statistički značajnu razliku određene ljekovite svojte između dva pašnjaka.

(95\%-tne granice pouzdanosti 11,7119,89 ), odnosno pripada 2 a i 2 b stupnju Braun-Blanquetove devetostupanjske skale.

U našim do sada neobjavljenim rezultatima HRZZ projekta IP-2016-063685 metodom GCMS-a ustvrđeno je da gospina trava (Hypericum perforatum L.), stolisnik (Achillea millefolium L.) i matičnjak (Melissa officinalis L.) s pašnjaka u Velikoj Crkvini sadrže terpene za koje je temeljem literaturnih podataka poznat njihov imunostimulacijski učinak (Kumar i sur., 2012., Zeng i sur., 2015, Balenović i sur., 2018., Ribeiro i sur., 2019., Valdivieso-Ugarte i sur., 2019., Yang i sur., 2019.). Tako je u našim, do sada neobjavljenim rezultatima HRZZ projekta IP-2016-06-3685, u svih procjenjivanih svojti pašnjaka Velike Crkvine GCMS metodom ustvrđeno prisustvo sljedećih monoterpena: $\alpha$-pinen, $\beta$-pinen, mircen i p-cimen, pri čemu je zabilježeno da je p-cimen zastupljen $\mathrm{u}$ aroma sastavu mesa janjadi uzgajanih u Velikoj Crkvini što se može povezati i s rezultatom ovoga rada o statistički značajno većoj učestalosti, gustoći i pokrovnosti ljekovitih svojti na pašnjaku u Velikoj Crkvini u odnosu na iste na pašnjaku u Kvarte.

Nadalje, temeljem literaturnih podataka poznato je da monoterpeni osim učinka na aroma profil mesa imaju i potencijalni imunomodulacijski učinak u životinja (Manuele i sur., 2008.). Navedenom u prilog govore izvrsni zdravstveni parametri jedinki (poput hematologije, biokemije, imunologije i mikrobiološke i koprološke analize) koje smo kroz projektne aktivnosti pratili i ustvrdili na pašnjacima u Velikoj Crkvini (Jelenčić, 2018., Žura Žaja i sur., 2019.). Stoga, s obzirom na rezulate procjene učestatolosti, gustoće i frekvencije procjenjivanih svojti pašnjaka Velike Crkvine $u$ odnosu na iste parametre pašnjaka u Kvarte (Tabela 1.), ne iznenađuju bolji imunosni status ovaca nakon napasivanja na pašnjacima u Velikoj Crkvini (Tabela 2). U ovim istraživanjima iako su dobiveni rezultati za glavne limfocitarne populacije iz periferne krvi ovaca neovisno o mjestu uzgoja u suglasju s referentnim vrijednostima koje je opisao za ovcu Tizard, (2004.), vidljivo je da su vrijednosti statistički značajno veće $u$ ovaca uzgajanih na pašnjacima u Velikoj Crkvini. Nadalje, s obzirom da su u kralješnjaka poznata dva tipa receptora T limfocita (engl. T Cell Receptors, TCR) povezanih sa CD3, a to su TCR- $\alpha \beta$ i TCR- $\gamma \delta$, u budućim istraživanjima od velike bi važnosti bilo ustvrditi i udjele T limfocita ovaca ovisno sadrži li njihov TCR receptor $\alpha-\mathrm{i}$ $\beta$ - ili $\gamma$-i $\delta$-lance. Naime, $\gamma \delta$ T-limfociti tek su djelomice opisani uz naznaku da su najučestaliji u crijevnoj sluznici i na mjestima u organizmu gdje koža prelazi 
Tabela 2. Srednje vrijednosti i standardna pogreška srednje vrijednosti T i B limfocita iz periferne krvi ovaca držanih na dva različita procjenjivana pašnjaka.

\begin{tabular}{l|c|c|c|c|}
\multirow{2}{*}{$\begin{array}{l}\text { PROCJENJIVANI } \\
\text { PAŠNJACI }\end{array}$} & \multicolumn{4}{|c|}{$\begin{array}{c}\text { SREDNJE VRIJEDNOSTI I STANDARDNA POGRĚKA SREDNJE } \\
\text { VRIJEDNOSTI T i B LIMFOCITA IZ PERIFERNE KRVI OVACA }\end{array}$} \\
\cline { 2 - 5 } & $\begin{array}{c}\text { pomoćnički } \\
\text { T-limfociti (\%) }\end{array}$ & $\begin{array}{c}\text { citolitički } \\
\text { T-limfociti (\%) }\end{array}$ & $\begin{array}{c}\text { memorijski } \\
\text { T-limfociti (\%) }\end{array}$ & B-limfociti (\%) \\
\hline VELIKA CRKVINA & $18,15 \pm 0,12$ & $10,87 \pm 0,10$ & $2,95 \pm 0,05$ & $24,46 \pm 0,15$ \\
\hline KVARTA & $17,65 \pm 0,11$ & $9,76 \pm 0,11$ & $2,80 \pm 0,06$ & $19,81 \pm 0,12$ \\
\hline VRIJEDNOST & $P<0,01$ & $P<0,0001$ & $P>0,05$ & $P<0,0001$ \\
\hline
\end{tabular}

u sluznicu pa se zbog toga nazivaju intraepitelnim limfocitima kojih je funkcija u lokalnoj obrani (Hajsig i sur., 2013.). Nadalje, u perifernoj krvi čovjeka i miša njihov je sadržaj vrlo mali za razliku u ovaca, goveda i svinje kod kojih mogu činiti do 15-60 \% mononuklearnih stanica periferne krvi (Piccinni i sur., 2015., Guerra-Maupome i sur., 2019., Andrišić i sur., 2020.).

\section{Zaključak}

Općenito je malo znanstvenih spoznaja o učinku zemljopisnog područja uzgoja, odnosno botaničkog sastava pašnjaka na aroma sastav janjećeg mesa, tako da su dobiveni podatci u ovom radu od velikog značenja. Očekuje se da će provedeno istraživanje pridonijeti daljnjim istraživanjima o mogućnostima, ne samo identifikacije i praćenja terpena kao specifičnih biljnih biomarkera u proizvodima i tkivima janjadi koji se pouzdano mogu povezati s načinom uzgoja i hranidbe, već i o njihovom istovremenom potencijalnom imunomodulacijskom učinku. Stoga su u ovom radu dobiveni rezultati znanstvena preporuka za daljnju procjenu biljnog sastava pašnjaka u Velikoj Crkvini tijekom istraživanja HRZZ projekta IP-2016-063685 u cilju postizanja dodatnih saznanja o učinku terpena na zdravlje i aroma sastav janjećeg mesa $i$ to sve $u$ svrhu proizvodnje inovativnih funkcionalnih proizvoda od janjećeg mesa.

\section{Zahvala}

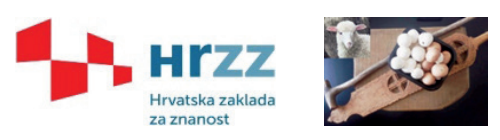

Ovaj je rad financirala Hrvatska zaklada za znanost projektom "Inovativni funkcionalni proizvodi od janjećeg mesa" (IP-2016-06-3685).

\section{Literatura}

1. ANDRIŠIĆ, M., I. ŽARKOVIĆ, K. ŠANDOR, A. VUJNOVIĆ, E. PERAK JUNAKOVIĆ, H. VALPOTIĆ, K. BENDELJA, Ž. CVETIĆ, F. BOŽIĆ and S. TERZIĆ (2020): Phenotype analysis of $\mathrm{CD}^{+} \mathrm{CD} 16^{+}$lymphocytes in the peripheral blood of pigs. Vet. stn. 51, 117-128.

2. BALENOVIĆ, M., V. SAVIĆ, Z. JANJEČIĆ, M. POPOVIĆ, B. ŠIMPRAGA, K. CAROVIĆ-STANKO, D. BEDEKOVIĆ and T. AMŠEL ZELENIKA (2018): Immunomodulatory and antimicrobial effects of selected herbs on laying hens. Vet. arhiv 88, 673-686.

3. BREITMAIER, E. (2006): Terpenes- Flavors, Fragrances, Pharmaca, Pheromones. Wiley- VCH Verlag GnbH \& Co. KgaA, London.

4. CVRTILA, Ž., M. POPOVIĆ, L. PAJURIN, D. JELENČIĆ, L. KOZAČINSKI, K. VLAHOVIĆ, B. ŠPOLJARIĆ, G. KIŠ, G. MRŠIĆ i D. ŠPOLJARIĆ (2018): Procjena kvalitete voluminozne krme pašnjaka farme ovaca pasmine Lička pramenka u vlasništvu GEA-COM d.o.o.. Zbornik radova Veterinarski dani 2018. / Harapin, I. (ur.). Zagreb: Tiskara Zelina d.d., 2018., str. 379-389.

5. GUERRA-MAUPOME, M., J. R. SLATE and J. L. McGILL (2019): Gamma Delta T Cell Function in Ruminants. Vet. Clin. N. Am. Food A 35, 453-469.

6. HAJSIG, D., Lj. PINTER, R. ANTOLOVIĆ i J. MADIĆ (2013): Veterinarska imunologija. Veterinarski fakultet Sveučilišta u Zagrebu, Zagreb.

7. JELENČIĆ, D. (2018): Uzgoj ovaca pasmine Lička pramenka, s posebnim osvrtom na zdravstveno 
stanje. Diplomski rad, Veterinarski fakultet Sveučilišta u Zagrebu.

8. KRVAVICA, M., I. VNUČEC, I. BRADAŠ, T. JUG, J. ĐUGUM i N. MARUŠIĆ-RADOVČIĆ (2015a): Isparljivi spojevi arome paške janjetine. Meso 17, 435-443.

9. KRVAVICA, M., I. VNUČEC, M. BRADAŠ, T. JUG, J. ĐUGUM i N. MARUŠIĆ RADOVČIĆ (2015b): Isparljivi spojevi arome ličke janjetine. Meso 17, 238-246.

10. KRVAVICA M., I. BOLTAR, M. BRADAŠ, J. TJAŠA, I. MARUŠIĆ i N. RADOVČIĆ (2015c): Isparljivi spojevi arome dalmatinske janjetine. Meso 17, 57-64.

11. KRVAVICA, M., J. ROGOŠIĆ, I. VNUČEC, J. TJAŠA, J. ĐUGUM i N. MARUŠIĆ-RADOVČIĆ (2016): Isparljivi spojevi arome creske janjetine. Meso 18, 53-63.

12. KRVAVICA, M., A. GANIĆ, M. BEGIĆ i J. ĐUGUM (2020): Hlapivi spojevi arome kupreške janjetine. Meso 18, 53-63.

13. KUMAR, D., A. VIKRANT, R. KAUR, Z. ALI BHAT, V. KUMAR GUPTA and V. KUMAR (2012): A review of immunomodulators in the Indian traditional health care system. J. Microbiol. Immunol. Infect. 45, 165-184.

14. MANUELE, M. G., G. FERRARO and C. ANESINI (2008): Effect of Tilia viridis flower extract on the proliferation of a lymphoma cell line and on normal murine lymphocytes: contribution of monoterpenes, especially limonene. Phytother. Res. 22, 1520 -1526.

15. MIOČ, B., V. PAVIĆ i V. SUŠIĆ (2007): Ovčarstvo. Hrvatska mljekarska udruga Zagreb, 62-64, 213-219.

16. MUJEZINOVIĆ, I., A. SMAJLOVIĆ, A. ZUKO, B. DUKIĆ and V. ĆUPIĆ (2018): Importance of clinical applications of thymol. Vet. stn. 49, 123-129. (In Croatian).

17. MULC, D., D. JURKOVIĆ, G. DUVNJAK, T. SINKOVIĆ, J. DAUD, N. LJEŠIĆ, M. ŠPEHAR i M. DRAŽIĆ (2012): Godišnje izvješće 2011. Ovčarstvo, kozarstvo i male životinje, Republika Hrvatska, HPA, Križevci 2012.

18. NIKOLIĆ, T. (2006): Flora: priručnik za inventarizaciju i praćenje stanja. Državni zavod za zaštitu prirode, Državni zavod za zaštitu prirode, Zagreb.

19. NIKOLIĆ, T. (2013): Sistematska botanikaraznolikosti evolucija biljnog svijeta. Udžbenici Sveučilišta u Zagrebu, Alfa, Zagreb.

20. PAJURIN, L., G. KIŠ, D. ŠPOLJARIĆ, V. ŠEGOTA, G. MRŠIĆ, K. VLAHOVIĆ, S. VINCE, B. ŠPOLJARIĆ i M. POPOVIĆ (2019a): Botanički sastav i hranjiva vrijednost pašnjaka s područja Velike Crkvine u hranidbi janjadi Ličke pramenke. Zbornik radova Veterinarski dani 2019. Primošten, Hrvatska, str. 253-262.

21. PAJURIN, L., Ž. CVRTILA, T. MIKUŠ, L. KOZAČINSKI, K. VLAHOVIĆ, D. ŠPOLJARIĆ, G. KIŠ, M. J. ČOP, I. BAČIĆ, V. ŠEGOTA and M. POPOVIĆ (2019b): Analysis of terpenes in Matricaria perforata and Thymus pulegioides on GEA-
COM ltd. pastures using GC-MS. $8^{\text {th }}$ International congress "veterinary science and profession" Book of abstracts. Zagreb, Croatia, p. 135.

22. PAJURIN, L., D. ŠPOLJARIĆ, G. KIŠ, K. VLAHOVIĆ, M. PAVLAK, S. VINCE, V. ŠEGOTA, B. ŠPOLJARIĆ, G. MRŠIĆ, Ž. CVRTILA, L. KOZAČINSKI and M. POPOVIĆ (2020): Abundance, density and coverage estimation of Thymus pulegioides L. on the pastures surrounding Velika Crkvina. Vet. stn. 51, 507-517.

23. PETERFALVI, A., E. MIKO, T. NAGY, B. REGER, D. SIMON, A. MISETA, B. CZÉH and L. SZEREDAY (2019): Much More Than a Pleasant Scent: A Review on Essential Oils Supporting the Immune System. Molecules 24, 4530. doi:10.3390/ molecules24244530.

24. PICCINNI, B., S. MASSARI, A. CAPUTI JAMBRENGHI, F. GIANNICO, M. P. LEFRANC, S. CICCARESE and R. ANTONACCI (2015): Sheep (Ovis aries) $\mathrm{T}$ cell receptor alpha (TRA) and delta (TRD) genes and genomic organization of the TRA/ TRD locus. BMC Genomics 16, Article number: 709, doi 10.1186/s12864-015-1790-z.

25. PRIOLO, A., A. CORNU, S. PRACHE, M. KROGMANN, N. KONDJOYAN, D. MICOL and J. L BERDAGUE (2004): Fat volatiles tracers of grass feeding in sheep. Meat Sci. 66, 475-481.

26. RIBEIRO, A. D. B., M. V. C. FERRAZ JUNIOR, D. M. POLIZEL, A. A. MISZURA, L. G. M. GOBATO1, J. P. R. BARROSO, I. SUSIN and A. V. PIRES (2019): Thyme essential oil for sheep: effect on rumen fermentation, nutrient digestibility, nitrogen metabolism, and growth. Arquivo Brasileiro de Medicina Veterinária e Zootecnia 71, 2065-2074.

27. SINKOVIĆ, T. i M. ČAČIĆ (2018): Godišnje izvješće o uzgoju ovaca, koza i malih životinja za 2017. godinu, Republika Hrvatska, HPA, izvješće za 2017. godinu, Križevci, str. 20.

28. TIZARD, I. R. (2004): Veterinary Immunology: An Introduction. Saunders, Philadelphia, Pennsylvania, USA.

29. TOPLAK, G. (2005): Domaće ljekovito bilje. Mozaik knjiga, Zagreb.

30. VALDIVIESO-UGARTE, M., C. GOMEZLLORENTE, J. PLAZA-DÍAZ and Á. GIL (2019): Antimicrobial, Antioxidant, and Immunomodulatory Properties of Essential Oils: A Systematic Review. Nutrients 11, doi: 10.3390/ nu11112786.

31. VANDEN BROECK A., T. CEULEMANA, G. KATHAGEN, M. HOFFMANN, O. HONNAY and J. MERGEAY (2016): Dispersal constraints for the conservation of the grassland herb Thymus pulegioides L. in a highly fragmented agricultural landscape. Conserv. Genet. 16, 765-776.

32. VALPOTIĆ, H., M. ŠPERANDA, A. KOVŠCAJANJATOVIĆ, M. ĐIDARA, G. LACKOVIĆ, F. BOŽIĆ, B. HABRUN, S. SREČEC, M. MATAUŠIĆPIŠL and I. VALPOTIĆ (2014): Levamisole stimulates proliferation of circulating and intestinal immune cell subsets, gut health and performance in weaned pigs. Can. J. Anim. Sci. 94, 43-53. 
33. VASTA, V. and A. PRIOLO (2006): Ruminant fat volatiles as affected by diet: A review. Meat Sci. 73, 218-228.

34. VINCE, S., M. PLATIŠA, J. GRIZELJ, B. ŠPOLJARIĆ, D. ĐURIČIĆ, F. SAMARTZI, H. VALPOTIĆ, V. BERTA, N. ROŠIĆ, B. STOJANOV and M. SAMARDŽIJA (2017): Determination of Physiological Particularities of the Sexual Cycle and Breeding Season of Pramenka Breed. Vet. stn. 48, 13-24. (In Croatian).

35. YANG, C., L. ZHANG, G. CAO, J. FENG, M. YUE, Y. XU, B. DAI, Q. HAN, and X. GUO (2019): Effects of dietary supplementation with essential oils and organic acids on the growth performance, immune system, fecal volatile fatty acids, and microflora community in weaned piglets. J. Anim. Sci. 97, 133143.

36. ZENG, Z., S. ZHANG, H. WANG and X. PIAO (2015): Essential oil and aromatic plants as feed additives in non-ruminant nutrition: a review. J. Anim. Sci. Biotechnol. 6:7, doi: 10.1186/s40104-0150004-5

37. ŽURA ŽAJA, I., S. VINCE, N. POLJIČAK MILAS et al. (2019): A new method of assessing sheep red blood cell types from their morphology. Animals (Basel) 9, 1130, doi:10.3390/ani9121130.

\section{The effect of the botanical composition of pastures on the immune status of the Lika Pramenka sheep breed}

Daniel ŠPOLJARIĆ, DVM, PhD, Assistant Professor, Ksenija VLAHOVIĆ, DVM, PhD, Full Professor, Tom MALONE, studen study in English, Silvijo VINCE, DVM, PhD, Associate Professor, Branimira ŠPOLJARIĆ, DVM, PhD, Assistant Professor, Maja POPOVIĆ, DVM, PhD, Full Professor, Faculty of Veterinary Medicine, University of Zagreb, Zagreb, Croatia; Goran KIŠ, BSc, PhD, Associate Professor, Faculty of Agriculture, University of Zagreb, Zagreb, Croatia; Indira MUJEZINOVIĆ, DVM, PhD, Full Professor, dr. sc. Amina HRKOVIĆ-POROBIJA, DVM, PhD, Associate Professor, Veterinary Faculty, University of Sarajevo, Sarajevo, Bosnia and Herzegovina; Luka PAJURIN, DVM, PhD student, Project Assistant at Croatian Science Foundation, Croatia; Vedran ŠEGOTA, BSc, PhD, Professional Associate, Faculty of Science, University of Zagreb, Zagreb, Croatia; Mirjana Marijana KARDUM PARO, BSc, PhD, Associate Professor, Univrsity Hospital Merkur, Zagreb, Croatia

The botanical composition of pastures in various areas, with special regard to terpene proportions, have an effect on the terpene profile of ruminant meat aroma, and may also have a potential immunomodulation effect in the animals. Therefore, assessments of pasture composition are of great interest to modern sheep breeding in Croatia. They study showed that medicinal plants with high terpene content, such as St. John's Wort (Hypericum perforatum L.), yarrow (Achillea millefolium L.) and lemon balm (Melissa officinalis L.) have a potential effect on improving immune status in sheep. The pastures of Velika Crkva had a statistically significant higher frequency, density and cover of these species than the pastures in Kvarte. Therefore, the results presented here contributed to the scientific recommendation for further assessment of the plant composition of pastures in Velika Crkvina during a separate study the research of the Croatian Science Foundation project IP-2016-06-3685 in order to gain additional knowledge about the effect of terpenes on the health and flavour composition of lamb meat and to contribute to the production of innovative and functional lamb meat products.

Key words: pasture; terpenes; sheep 